\title{
From Factory Floor to Killing Floor: Marx, Critical Theory and the Status of the Animal
}

\author{
Amy Buzby ${ }^{*}$
}

Despite Marx and Engels' imperative to "support every revolutionary movement against the existing social and political order of things," Marxism's relationship with animal rights activism is problematically vague. In this paper, I argue that absent the rejection of the exploitation of non-human animals, it is impossible to apprehend the full "web of domination" operating in the present. I frame the status of the non-human animal as a nodal point at which the domination of all living creatures, including humans, by and for capital becomes clear as a fixed aspect of capitalism. I also contest that any Marxian praxis that fails to encompass the status and claims on behalf of nonhuman animals artificially forecloses a fruitful space for struggle that can be used to agitate for change that stretches far beyond the treatment of non-human animals. [Article copies available for a fee from The Transformative Studies Institute. E-mail address: journal@transformativestudies.org

http://www.transformativestudies.org (C2015 by The Transformative Studies Institute. All rights reserved.]

KEYWORDS: Marx, Critical Theory, Animal Ethics.

Considerations of the status of animals in contemporary society should start from the recognition that the most thorough domestication undertaken by man has been that of the human species itself. Man has been progressively alienated, indeed, through the human conquest of nature, including that of non-human animals. Human domination of

\footnotetext{
* Amy Buzby, Ph.D., is an assistant professor of political science at Arkansas State University. She received her doctorate in political science from Rutgers University - New Brunswick in 2011. She is also a former academic fellow of the Psychoanalytic Center of Philadelphia. Her published work includes a monograph, Subterranean Politics and Freud's Legacy: Critical Theory and Society, an edited volume, Communicative Action: The Logos Interviews, and several articles and book chapters. Her research interests include critical theory, psychoanalysis, Marxism and animal rights. Address correspondence to: Amy Buzby, Arkansas State University, PO Box 1750, 72467; e-mail: abuzby@astate.edu.
} 